doi: https://doi.org/10.15407/microbiolj83.03.092

\title{
BIOTECHNOLOGICAL POTENTIAL OF THE ACINETOBACTER GENUS BACTERIA
}

\author{
T.P. Pirog ${ }^{1,2}$, D.A. Lutsai ${ }^{1}$, F.V. Muchnyk ${ }^{2}$ \\ ${ }^{1}$ National University of Food Technologies, \\ 68 Volodymyrska Str., Kyiv, 01601, Ukraine \\ ${ }^{2}$ Zabolotny Institute of Microbiology and Virology, NAS of Ukraine, \\ 154 Acad. Zabolotny Str., Kyiv, 03143, Ukraine \\ e-mail:tapirog@nuft.edu.ua
}

\begin{abstract}
Until recently, there were rare scientific reports on the biotechnological potential of non-pathogenic bacteria of the Acinetobacter genus. Although the first reports about the practically valuable properties of these bacteria date back to the 70s and 80s of the twentieth century and concerned the synthesis of the emulsan bioemulsifier. In the last decade, interest in representatives of the Acinetobacter genus as objects of biotechnology has significantly increased. The review presents current literature data on the synthesis by bacteria of this genus of high-molecular emulsifiers, low-molecular biosurfactants of glyco- and aminolipid nature, enzymes (lipase, agarase, chondroitinase), phytohormones, as well as their ability to solubilize phosphates and decompose various xenobiotics (aliphatic and aromatic hydrocarbons, pesticides, insecticides). Prospects for practical application of Acinetobacter bacteria and the metabolites synthesized by them in environmental technologies, agriculture, various industries and medicine are discussed. The data of own experimental studies on the synthesis and biological activity (antimicrobial, anti-adhesive, ability to destroy biofilms) of biosurfactants synthesized by A. calcoaceticus IMV B-7241 strain and their role in the degradation of oil pollutants, including complex ones with heavy metals, are presented. The ability of A. calcoaceticus IMV B-7241 to the simultaneous synthesis of phytohormones (auxins, cytokinins, gibberellins) and biosurfactants with antimicrobial activity against phytopathogenic bacteria allows us to consider this strain as promising for practical use in crop production to increase crop yields.
\end{abstract}

Keywords: Acinetobacter genus, biosurfactants, bioemulsifiers, enzymes, phytohormones, degradation of xenobiotics.

Among the bacteria that produce practically important metabolites, there are peculiar "record holders" that are capable of synthesizing a wide range of biologically active agents. They include representatives of the generitypes Bacillus and Paenibacillus [1-3], Streptomyces [4, 5], Pseudomonas [6, 7], and Rhodococcus [8, 9].

In the last decade, more and more information has emerged about the bacteria of the genus Acinetobacter. If in 1986 only two species of this genus were described (Acinetobacter calcoaceticus and Acinetobacter lwoffii [10]), then currently they are about 78 [www.bacterio.net]. Interest in representatives of the genus Acinetobacter is due to the following reasons. First, these bacteria are found in various natural places of existence (soil, fresh water, oceans, sediments, areas contaminated with xenobiotics) $[10,11]$. Secondly, universal catabolic pathways and broad substrate specificity of metabolic systems ensure their active participation in the cycle of matters in nature [10]. Thirdly, Acinetobacter baumannii strains are characterized by multiple antibiotic resistance and cause healthcare-associated infections with heavy mortality [11-13]. Fourthly, nonpathogenic representatives of the genus Acinetobacter are capable of synthesizing practically valuable compounds: bioemulsifiers [14-16], smallmolecule biosurfactants (surface-active agent) $[17,18]$, enzymes $[19,20]$, gibberellins $[21,22]$. Fifthly, these bacteria are promising for use in environmental technologies due to their ability to effectively destroy various xenobiotics [23-25].

The purpose of this review is to analyze and summarize literature data as well as own experimental studies on the use of Acinetobacter 
genus bacteria as potential biological agents in biotechnological processes.

Synthesis of practically important metabolites by Acinetobacter genus bacteria

The first practically valuable final product produced by Acinetobacter genus bacteria was emulsan. In the late 70 s of the twentieth century, information appeared in the literature about the isolation of acidic etherified by fatty acids of a high-molecular exopolysaccharide synthesized by A. calcoaceticus (Arthrobacter) RAG-1 [26-28]. The polysaccharide was called emulsan due to its ability to emulsify hydrophobic substrates containing aliphatic, aromatic and cyclic components.

Biosurfactants. Reports on the ability of representatives of this genus to synthesize lowmolecular biosurfactants date back to 2009 [29-31].

Subsequent reports of new strains of the genus Acinetobacter capable of biosurfactant synthesis appeared in 2012-2013 [17, 32, 33].
During 2014-2020, about a dozen papers were published that reported on the synthesis of biosurfactants by representatives of the genus Acinetobacter on hydrophobic (petroleum, diesel fuel, oil) [18, 34-42] and hydrophilic (glucose, saccharose, glycerol, ethanol, tryptone) [38, 43-45] substrates. In 2019, brief information about some producers of biosurfactants was provided in the review [46].

It should be noted that in many papers [36, $40,43-45]$, the authors did not determine the concentration of biosurfactants, and the ability to synthesize these metabolites was evaluated by reducing the surface tension and/or emulsifying index of the cell-free culture fluid. This is due to the fact that the main research of these works' authors is aimed at the potential use of biosurfactants in environmental technologies for the destruction of xenobiotics, and the formation of biosurfactants is considered as an additional property of microbes capable to destruct hydrophobic toxic compounds.

It is worth mentioning that the concentration of biosurfactants synthesized by representatives of

\section{Table 1}

\section{Biosurfactants of Acinetobacter genus bacteria}

\begin{tabular}{|c|c|c|c|c|}
\hline Strain & $\begin{array}{l}\text { Carbon source, } \\
\text { concentration }\end{array}$ & $\begin{array}{c}\text { BS concen-tration, } \\
\mathrm{g} / \mathrm{L}\end{array}$ & $\begin{array}{l}\text { Chemical nature } \\
\text { of biosurfactants }\end{array}$ & References \\
\hline \multicolumn{5}{|c|}{ Hydrophobic substrates } \\
\hline A. baumannii MKS2 & Crude oil, $1 \%$ & 0.12 & Glycolipids & [39] \\
\hline Acinetobacter sp. D3-2 & Crude oil, $0.5 \%$ & 0.52 & Lipopeptides & [35] \\
\hline A. bouvetii $\mathrm{BP} 18$ & $\begin{array}{l}\text { Crude oil, 3\%, } \\
\text { Diesel fuel, } 2 \%\end{array}$ & 0.17 & - & {$[37]$} \\
\hline A. pittii $\mathrm{ABC}$ & Hexadecane, $1 \%$ & 0.57 & Lipopeptides & [41] \\
\hline A. junii $\mathrm{BD}$ & $\begin{array}{c}\text { Refined soybean oil, } \\
80 \mathrm{~g} / \mathrm{L}\end{array}$ & 4.0 & Rhamnolipids & [18] \\
\hline $\begin{array}{l}\text { A. calcoaceticus IMV } \\
\text { B-7241 }\end{array}$ & $\begin{array}{c}\text { Waste oil after frying } \\
\text { meat, } 4 \%\end{array}$ & 8.5 & $\begin{array}{c}\text { Complex of glyco-, } \\
\text { amino- and neutral lipids }\end{array}$ & [47] \\
\hline $\begin{array}{l}\text { A. calcoaceticus IMV } \\
\text { B-7241 }\end{array}$ & $\begin{array}{l}\text { Waste oil after frying } \\
\text { farm potatoes, } 6 \%\end{array}$ & 7.9 & $\begin{array}{c}\text { Complex of glyco-, } \\
\text { amino- and neutral lipids }\end{array}$ & [47] \\
\hline \multicolumn{5}{|c|}{ Hydrophilic substrates } \\
\hline $\begin{array}{l}\text { A. calcoaceticus } \\
\text { K-4 (IMV B-7241) }\end{array}$ & Ethanol, $2 \%$ & $3.6^{*}$ & $\begin{array}{l}\text { Glyco- and amino-lipid } \\
\text { complex }\end{array}$ & [30] \\
\hline $\begin{array}{l}\text { A. calcoaceticus IMV } \\
\text { B-7241 }\end{array}$ & $\begin{array}{l}\text { Waste of biodiesel } \\
\text { production, } 7 \%\end{array}$ & 5.0 & $\begin{array}{l}\text { Glyco- and amino-lipid } \\
\text { complex }\end{array}$ & [48] \\
\hline $\begin{array}{l}\text { A. calcoaceticus NRRL } \\
\text { B-59190 }\end{array}$ & Purified glycerol, $1 \%$ & 2.0 & Rhamnolipids & [31] \\
\hline $\begin{array}{l}\text { A. calcoaceticus NRRL } \\
\text { B-59191 }\end{array}$ & Purified glycerol, $1 \%$ & 2.2 & Rhamnolipids & [31] \\
\hline A. calcoaceticus B-59190 & Sodium citrate, $20 \mathrm{~g} / \mathrm{L}$ & 2.0 & Rhamnolipids & [34] \\
\hline A. baumannii MN3 & Saccharose, $4 \%$ & 4.68 & Lipopeptides & [34] \\
\hline
\end{tabular}

Legend: BS - biosurfactants, * - conditional biosurfactant concentration, "-_" - no data. 
the genus Acinetobacter on hydrocarbon substrates (petroleum, hexadecane) established in the papers $[35,37,39,41]$ was low and amounted to only $0.12-0.57 \mathrm{~g} / \mathrm{L}$. Parthipan et al. [38] found that the concentration of synthesized biosurfactants reached $4.68 \mathrm{~g} / \mathrm{L}$ when $A$. baumannii MN3 growing on an optimized medium (saccharose concentration $4 \%$, nitrogen source - urea).

In 2018, we published the paper [47], in which we reported on the ability of $A$. calcoaceticus IMV B-7241 strain to synthesize biosurfactants on waste (overcooked) sunflower oil of various qualities.

It should be noted that to date, there is no information in the literature on the synthesis of biosurfactants by Acinetobacter genus bacteria on waste oil. There is also no information on the use of biodiesel production waste for the production of biosurfactants by representatives of this genus. Our studies [48] showed that during the cultivation of A. calcoaceticus IMV B-7241 on this industrial waste $(7 \%)$, the biosurfactant concentration was $5 \mathrm{~g} / \mathrm{L}$.

Summarized information on the synthesis of biosurfactants by Acinetobacter bacteria is given in Table 1.

It should be noted that Table 1 includes only information on the producer for which the concentration of synthesized biosurfactants in $\mathrm{g} / \mathrm{L}$ is established. The data shown in Table 1 indicate that strain A. calcoaceticus IMV B-7241 is more efficient producer of biosurfactants than described in the literature. Thus, this strain synthesizes biosurfactants in sufficiently high concentrations $(5.0-8.5 \mathrm{~g} / \mathrm{L})$ on various hydrophilic and hydrophobic substrates, including industrial waste.

Until recently, there was no information in the literature about the biological activity of biosurfactants of Acinetobacter genus bacteria. Only in 2020, information appeared about the antimicrobial, antineoplastic activity and ability to destroy bacteria films of biosurfactants $A$. junii $\mathrm{B} 6$ [42] and A. indicus M6 [45].

Thus, it is reported in the paper [45] that complete inhibition of the growth of methicillinresistant biological strains was observed in the presence of biosurfactants A. indicus M6 in concentration $(\mathrm{mg} / \mathrm{mL})$ : Escherichia coli, Pseudomonas aeruginosa - 20; Streptococcus epidermis - 50; Klebsiella pneumoniae and Candida albicans - 100. Treatment of biofilms for 7 days with a solution of biosurfactants $(500 \mathrm{mg} / \mathrm{mL})$ was accompanied by their destruction by $80-82 \%$. In the presence of biosurfactants of strain A. indicus M6 at a concentration of
$200 \mathrm{mg} / \mathrm{mL}$ showed a significant decrease in lung cancer cells (A549) due to inhibition of their proliferation in the G1 phase.

Minimum inhibitory concentrations (MIC) of biosurfactants A. junii B6 against Staphylococcus aureus ATCC 29213, Bacillus subtilis ATCC 6051, Micrococcus luteus ATCC 4698, P. aeruginosa ATCC 27853, K. pneumonia ATCC 13883, E. coli ATCC 25922, Salmonella typhi ATCC 6539, C. albicans ATCC 10231 and Candida utilis ATCC 9950 were $5 \mu \mathrm{g} / \mathrm{mL}$ [49]. In the presence of biosurfactants at concentrations of 1250 and $2500 \mu \mathrm{g} / \mathrm{mL}$, the degree of destruction of biofilms reached (\%): Proteus mirabilis -10 and 30; S. aureus -30 and 50; P. aeruginosa -30 and 70 , respectively. The $\mathrm{IC}_{50}$ index used to evaluate the cytotoxic effect of biosurfactants on $\mathrm{U} 87, \mathrm{~KB}$, and HUVEC cancerous cells was $(\mathrm{mg} / \mathrm{mL}): 7.8 \pm 0.4$, $2.4 \pm 0.5$, and $5.7 \pm 0.1$, respectively [42].

Our first studies of the antimicrobial and antiadhesive activity of biosurfactants synthesized by $A$. calcoaceticus IMV B-7241 on various substrates (ethanol, hexadecane, refined glycerol) date back to 2014-2016 [49-51]. In 2017 [52], it was established that biosurfactants of IMV B-7241 strain are effective decomposers of bacterial and yeast biofilms. More recent studies $[53,54]$ have shown that biosurfactants synthesized by $A$. calcoaceticus IMV B-7241 on industrial waste (waste oil of various quality and biodiesel production waste) is also characterized by high antimicrobial, anti-adhesive activity and the ability to biofilm destruction.

MIC of A. calcoaceticus IMV B-7241 biosurfactants in relation to some test-cultures, the adhesion of bacterial and yeast cells on the abiotic surface treated with biosurfactant, as well as the effect of biosurfactants on biofilm destruction is shown in Table 2.

These data indicate that the biosurfactants of IMV B-7241 strain exhibit high anti-adhesive activity (adhesion 22-47 \%) and effectively destroyed biofilms (41-83 \%) at a lower concentration $(2.5-320 \mu \mathrm{g} / \mathrm{mL})$ than synthesized by $A$. junii B6 (1250 and $2500 \mu \mathrm{g} / \mathrm{mL})$ [42] and by A. indicus M6 $(500 \mu \mathrm{g} / \mathrm{mL})$ [45].

So, despite the fact that the biosurfactants of Acinetobacter genus bacteria have been the target of scientific research for only ten years, currently some of them are competitive in the market of these microbial synthesis products. Firstly, they can be obtained in sufficiently high concentrations (up to 7-8 g/L) on cheap and available in large amounts industrial waste; secondly, they are promising not 
Table 2

Biological activity of Acinetobacter calcoaceticus IMV B-7241 biosurfactants

\begin{tabular}{|c|c|c|c|c|}
\hline Substrate & Test culture & $\mathrm{MIC}, \mu \mathrm{g} / \mathrm{mL}$ & $\begin{array}{c}\text { Adhesion on polyvinyl } \\
\text { chloride *, } \%\end{array}$ & $\begin{array}{l}\text { Destruction of } \\
\text { biofilm**, \% }\end{array}$ \\
\hline \multirow{3}{*}{ Ethanol } & B. subtilis БТ-2 & 9 & 33 & $69(80)$ \\
\hline & E. coli IEM-1 & 20 & 22 & $49(320)$ \\
\hline & C. albicans Д-6 & 9 & 27 & N.d. \\
\hline \multirow{3}{*}{ Purified glycerol } & B. subtilis БТ-2 & 9 & 25 & $87(320)$ \\
\hline & E. coli IEM-1 & 34 & 33 & $41(320)$ \\
\hline & C. albicans Д-6 & 68 & 25 & $42(320)$ \\
\hline \multirow{3}{*}{ Hexadecane } & B. subtilis БТ- 2 & 27 & 33 & $57(320)$ \\
\hline & E. coli IEM-1 & 11 & 45 & $45(320)$ \\
\hline & C. albicans Д-6 & 54 & 47 & $42(320)$ \\
\hline \multirow{3}{*}{$\begin{array}{l}\text { Waste of biodiesel } \\
\text { production }\end{array}$} & B. subtilis БТ- 2 & 0.96 & N.d. & N.d. \\
\hline & E. coli IEM-1 & 3.8 & N.d. & N.d. \\
\hline & C. albicans Д-6 & 15.2 & 86 & N.d. \\
\hline \multirow{3}{*}{$\begin{array}{l}\text { Waste oil after frying } \\
\text { farm potatoes }\end{array}$} & B. subtilis БТ-2 & 28.8 & 34 & $63(233)$ \\
\hline & E. coli IEM-1 & 0.9 & N.d. & $83(29)$ \\
\hline & C. albicans Д-6 & 57.6 & 44 & N.d. \\
\hline
\end{tabular}

Legend: N.d. - not determined; "*” - surfactant concentration of $2.5-5.0 \mu \mathrm{g} / \mathrm{mL}$; “**” - in parentheses indicates the concentration of biosurfactants, $\mu \mathrm{g} / \mathrm{mL}$.

only for the degradation of xenobiotics, but due to their antimicrobial, anti-adhesive, antineoplastic properties - for potential use in the pharmaceutical industry and medicine.

Bioemulsifiers. The producer of the highmolecular bioemulsifier emulsan was initially identified as a representative of the genus Arthrobacter RAG-1 [26-28], but later assigned to the genus Acinetobacter, which at that time included only one species - A. calcoaceticus [55]. In the international American typical culture collection, the strain is registered as A. lwoffii. In 1999, the emulsan-producing strain was renamed and assigned to type $A$. venetianus [56]. In the second half of the 80 s of the twentieth century, there was information on A. calcoaceticus BD4 strain, capable of emulsan synthesis [57] and A. calcoaceticus $\mathrm{A} 2$ as a producer of biodispersan $[58,59]$. In the 90 s of the twentieth century, the bioemulsifier alasan synthesized by $A$. radio resistens KA53 was described [60].

A brief description of emulsan, alasan, and biodispersan is given in Table 3 .

In 2008 [62], it was found that apoemulsan RAG-1 (protein-free emulsan) is a complex consisting of a high-molecular exopolysaccharide and an R-type lipopolysaccharide. The exopolysaccharide has a molecular weight of 200 $250 \mathrm{kDa}$ and is able to form stable emulsions of the "oil in water" type.

The highest concentration of emulsan and dispersan $(4-5 \mathrm{~g} / \mathrm{L})$ was achieved under cultivation of $A$. venetianus RAG-1 and A. calcoaceticus A2 on medium with ethanol $[58,61]$.

Information on the practical use of emulsan and alasan, the main ones being environmental cleaning from xenobiotics, oil transportation and cleaning of tankers from oil, is provided in the reviews [46, 61, $63,64]$. Due to the ability of biodispersan to change the surface properties of limestone and increase its dispersion in aqueous solutions, it is promising for use in the production of paper, paint and ceramics $[46,59]$.

Over the past ten years, the literature has described new emulsifiers synthesized by representatives of the genus Acinetobacter [14-16, $65,66]$ on hydrocarbon $[14,15]$, oil-containing $[16,66]$, hydrophilic (ethanol, tryptone) $[65,66]$ substrates, as well as on mixtures of glycerol and hexadecane [66]. By their chemical nature, bioemulsifiers are glycoproteins [14, 16, 65], lipopolysaccharides [66], and polysaccharides [15].

Table 4 shows summarized information on emulsifiers studied during 2010-2019 years. These data indicate that the most active producers are A. beijerinckii ZRS, Acinetobacter sp. Ab9-ES and Acinetobacter sp. Ab33-ES strains, which synthesize from 4 to $5 \mathrm{~g} / \mathrm{L}$ of the final product with high emulsifying activity.

So, bioemulsifiers of Acinetobacter genus bacteria, which were first described more than 40 years ago, and still remain the target of scientific research. This is primarily due to the fact that, unlike 
other products of microbial synthesis synthesized by a wide range of bacteria, these emulsifiers are a "kind of business card" of Acinetobacter genus representatives.

Enzymes. Over the past 10 years, a number of papers have been published that have established the ability of Acinetobacter genus bacteria to synthesize various hydrolytic enzymes: lipases (EC 3.1.1.3) [20, 67-74], agarases (EC 3.2.1.81) $[75,76]$, chitinases (EC 3.2.1.14), gelatinases (EC 3.4.24) [70], including cold-active ones [67, $68,70]$, as well as chondroitinases (EC 4.2.2.4) [19].

Most of the research is devoted to the synthesis of lipases, which are promising for use in various areas of the chemical industry (detergents, chemical synthesis). It should be noted that the first reports on the synthesis of these enzymes by representatives of the genus Acinetobacter date back to the 80-90s of the twentieth century, and in 2004 a review was published [77], which summarized the relevant information available at that time. In our review, we provide information on the lipases of Acinetobacter genus bacteria, which appeared in the last decade (Table 5).

Agarase enzymes can be used for processing seaweed biomass and their further application in the production of biofuels $[75,76]$.

Zhu et al. [19] found that Acinetobacter sp. C26 strain synthesizes a unique enzyme, chondroitinase, which is promising in the treatment of spinal cord traumas. The papers [78-81] state that spinal cord traumas are a destructive condition that has no effective treatment at the moment. This condition occurs due to the inability of central nervous system neurons to regain after trauma. This is partly due to the presence of chondroitin sulfate molecules in the environment of the damaged spinal cord, which block the recovery process. The enzyme chondroitinase split these molecules, thereby promoting nerve regeneration and functional recovery. Chondroitinase can also promote neuroprotection of injured neurons $[78,79]$.

It should be noted that the first reports of microbial synthesis of chondroitinase by Bacteroides stercoris $\mathrm{HJ}-15$ strain appeared in 2002 [82]. This strain synthesized type ASII chondroitinase, whose activity in the supernatant was $0.42 \mathrm{U} / \mathrm{mL}$. The Sphingomonas paucimobilis strain (the strain number is not given) was somewhat more productive (the strain number is not given): the activity of ABC-type chondroitinase reached $0.94 \mathrm{U} / \mathrm{mL}$ [83]. The recombinant strain Pichia pastoris $\mathrm{X} 33$ synthesized chondroitinase with the activity of $2.72 \mathrm{U} / \mathrm{mL}$ [84], which is several times lower compared to that of Acinetobacter sp. C26 (8.5 U/mL) [19].

The summarized data on the synthesis of enzymes by representatives of the Acinetobacter genus are given in Table. 5. It should be noted that while Acinetobacter sp. XMZ-26 lipase producer is characterized by the highest synthesizing capacity compared to other bacteria of this genus, it is significantly inferior to the promising producer of Aspergillus tamarii JGIF06, which synthesizes lipase on a coconut oil medium with an activity of $25,000 \mathrm{U} / \mathrm{mL}$ [71]. At the same time, the Acinetobacter sp. AG LSL-1 strain, as an agarase producer (activity $3 \mathrm{U} / \mathrm{mL}$ ) is more promising than Alteromonas sp. C-1 (activity $2.3 \mathrm{U} / \mathrm{mL}$ ), which was discovered more than 15 years ago and was considered one of the most active producers of this enzyme (cited for [75]). The Acinetobacter sp.C26 strain is a more active producer of the unique chondroitinase enzyme (activity $8.5 \mathrm{U} / \mathrm{mL}$ ) compared to the recombinant Pichia pastoris X33 strain $(2.72 \mathrm{U} / \mathrm{mL})$ [84].

Phytohormones. Bacteria of the Acinetobacter genus are common in the soil, some of them are associated with plants, have a positive effect on their growth and development, including due to the ability to synthesize phytohormones $[21,22$, 85-90].

The first reports on the synthesis of phytohormones by representatives of the Acinetobacter genus appeared about ten years ago [21, 22, 85]. Thus, a group of scientists from Korea [21] found that strain A. calcoaceticus SE370 formed ten different gibberellins, including biologically active $\mathrm{GK}_{1}, \mathrm{GK}_{3}$, and $\mathrm{GK}_{4}(0.45-6.25 \mathrm{ng} / 100 \mathrm{~mL}$ of culture fluid). Gulati et al. [22] showed that the phosphateimmobilizing strain A. rhizosphaerae BIHB 723 synthesized indoleacetic acid (IAA) in the amount of $15.6 \mathrm{ng} / \mathrm{mL}$. In the paper [85] was found that two strains of Acinetobacter sp. PUCM1007 and A. baumannii PUCM1029 produced indoleacetic acid in a sufficient high concentration (10$13 \mu \mathrm{g} / \mathrm{mL}$ ). We assume that the increased synthesis of IAA by these strains is due to the presence of a precursor of tryptophan auxins biosynthesis $(0.3 \mathrm{~mm})$ in the culture medium.

Later, in 2014 Zhao et al. [86] showed that A. calcoaceticus D10, when cultivated in a medium with saccharose and tryptophan $(100 \mathrm{mg} / \mathrm{L})$ formed $22.77 \mathrm{mg} / \mathrm{L}$ of indoleacetic acid. In 2018 [87], there was a report on the synthesis of IAA $(2.8 \mu \mathrm{g} / \mathrm{mL})$ by the Acinetobacter sp. UQ202 strain 


\begin{tabular}{|c|c|c|c|c|c|}
\hline & 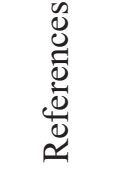 & 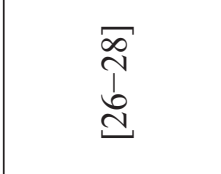 & $\begin{array}{l}\bar{\sigma} \\
\tilde{n}\end{array}$ & $\begin{array}{l}\bar{\sigma} \\
8 \\
8\end{array}$ & $\begin{array}{l}\bar{n} \\
n \\
\infty \\
n\end{array}$ \\
\hline & 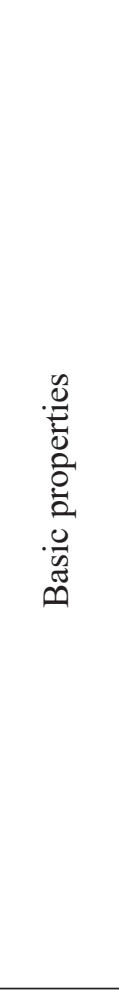 & 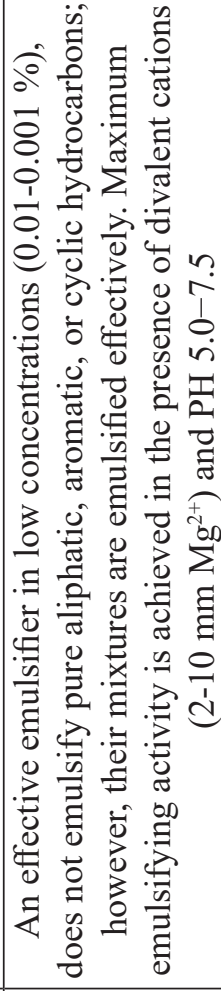 & 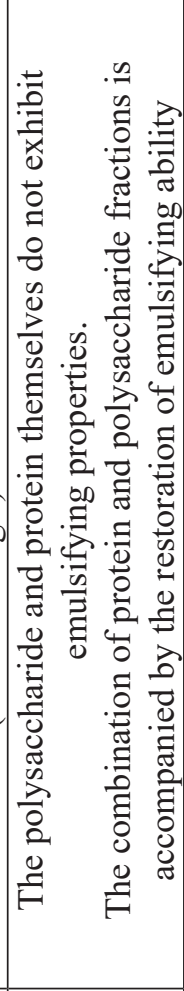 & 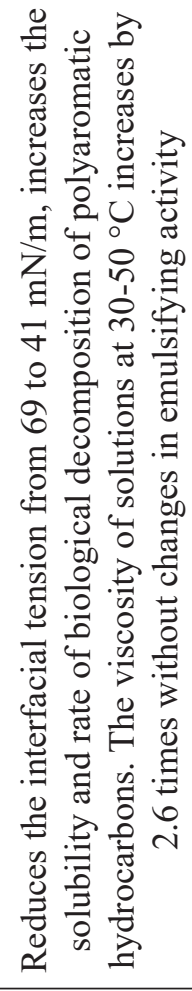 & 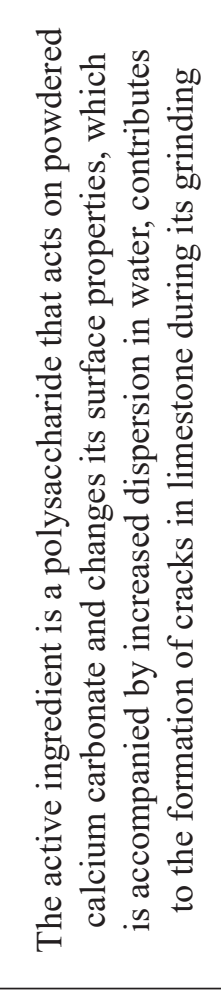 \\
\hline 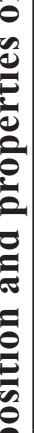 & 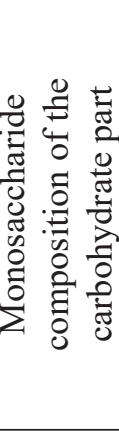 & 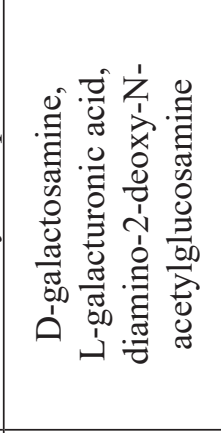 & 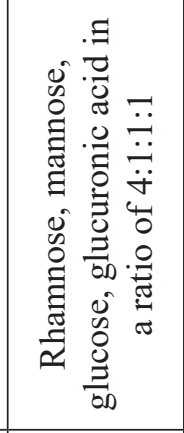 & 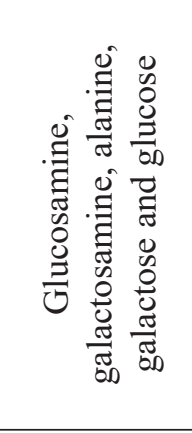 & 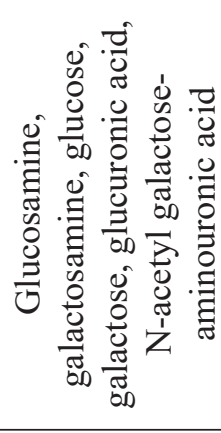 \\
\hline לֶ. & 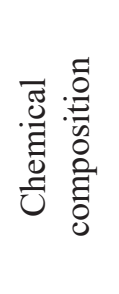 & 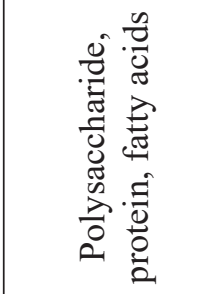 & 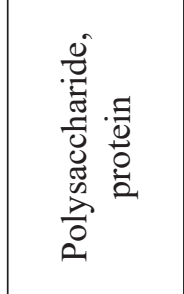 & 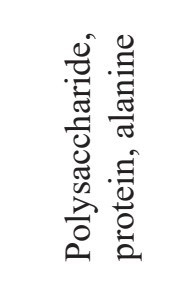 & 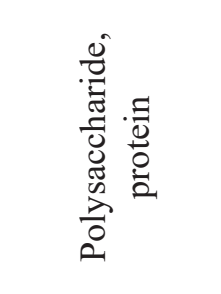 \\
\hline & 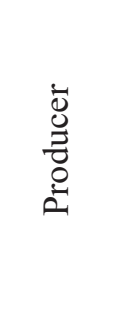 & 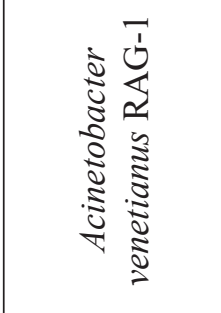 & 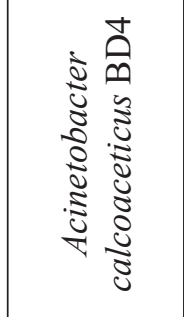 & 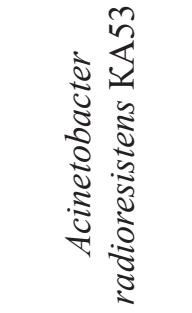 & 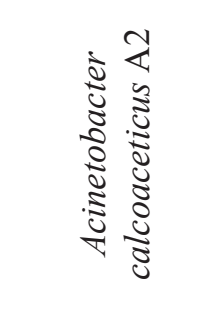 \\
\hline & 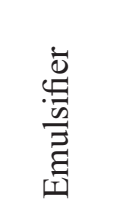 & 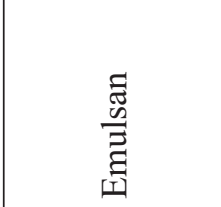 & 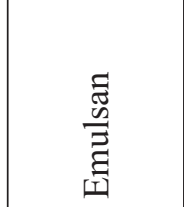 & $\bar{\psi}$ & 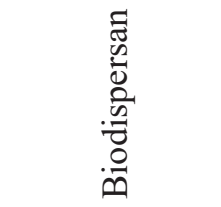 \\
\hline
\end{tabular}




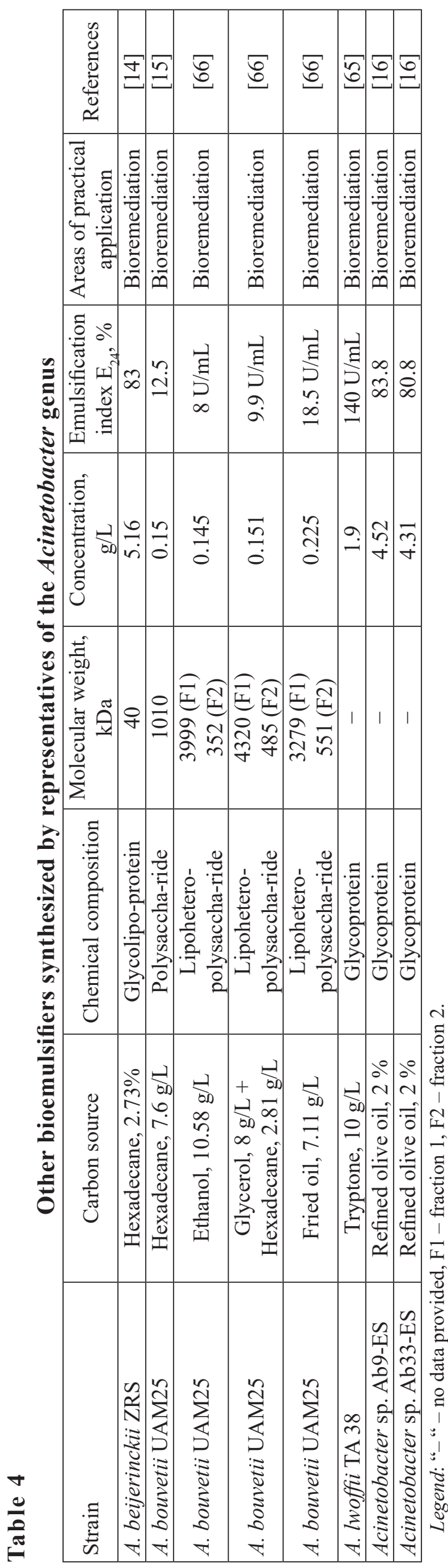

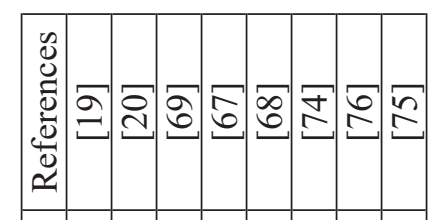

$\cdot \stackrel{0}{\stackrel{0}{\Xi}}$

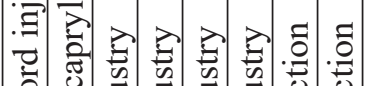

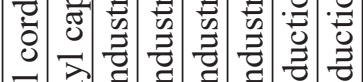

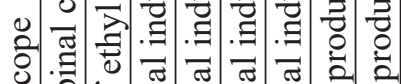
岂

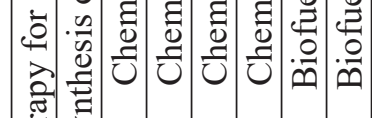
氙

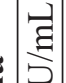

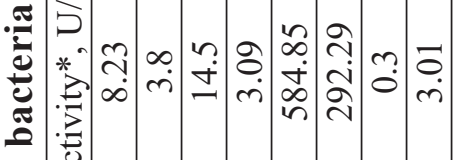
结

ప్

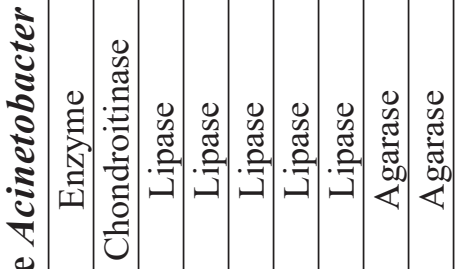

$\stackrel{乛}{=}$

0

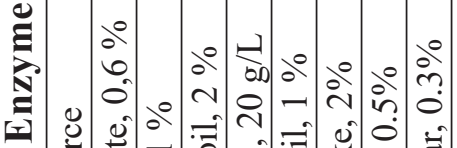

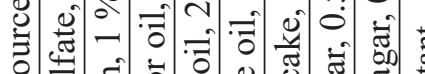

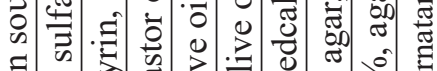

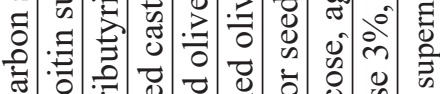

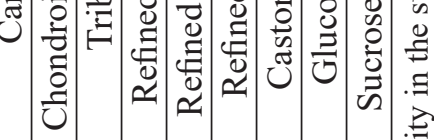

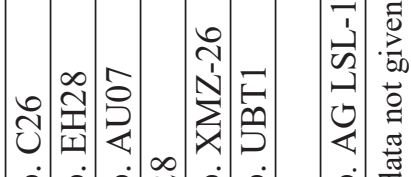
को के की की के के क्ते

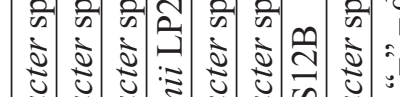

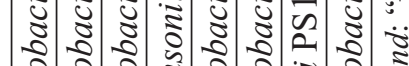

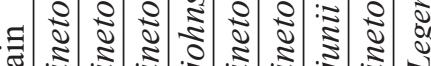
. 
under cultivation in a medium with tryptone and tryptophan $(800 \mu \mathrm{g} / \mathrm{mL})$.

Our studies $[89,90]$ have shown that $A$. calcoaceticus IMV B-7241 strain, when cultivated on various substrates, including industrial waste (technical glycerol, biodiesel production waste), synthesizes phytohormones of auxin, cytokinin and gibberellin nature. During cultivation on ethanol and technical glycerol, the concentration of phytohormones $(\mu \mathrm{g} / \mathrm{l})$ was: auxins -104.2 and 122.0; cytokinins -3.5 and 363.9 [90]; biologically active gibberellin $\mathrm{GK}_{4}-6.88$ and 7.36 [90].

In subsequent studies [91], we established the possibility of a significant increase of auxin synthesis when tryptophan (100-300 mg/L) is introduced into the medium cultivation of A. calcoaceticus IMV B-7241. Thus, in the presence of a precursor of auxin biosynthesis in a medium with biodiesel production waste, the concentration of phytohormones reached $1405-4851 \mu \mathrm{g} / \mathrm{L}$.

It should be noted that the ability of A. calcoaceticus IMV B-7241 strain to the simultaneous synthesis of phytohormones of auxin, cytokinin and gibberellin nature [89-91], as well as biosurfactants with antibacterial activity against phytopathogenic bacteria [92] makes it promising for use in agriculture to increase plant yield and phytopathogenic bacteria quantity control.

\section{Ability of Acinetobacter bacteria to phos- phates solubilization and xenobiotics deg- radation}

Phosphate mobilizing. Phosphate-solubilizing rhizobacteria (PSRB) improve soil fertility by converting insoluble forms of phosphorus to soluble plant-available forms [93, 94]. The source of PSRB isolation is soils that are deficient in soluble phosphates. The ability of PSRB to solubilize phosphates is due to the synthesis of organic acids, which either directly dissolve mineral phosphates as a result of solvolysis, or chelate iron, aluminum and calcium ions from phosphates [21, 22, 93, 94].

The study of Acinetobacter genus bacteria as phosphate-mobilizing agents began simultaneously with the study of their ability to synthesize growth-stimulating metabolites (phytohormones, siderophores, etc.) [21, 22, 87].

In the papers $[22,93]$ was established that A. rhizosphaerae BIHB 723 strain solubilized calcium triphosphate, as well as rock phosphates. During the cultivation of the BIHB 723 strain in a medium with glucose and $0.5 \%$ of various insoluble phosphates, organic acids (gluconic, 2-keto-gluconic, oxalic, malic, formic) were synthesized, and the qualitative and quantitative content of acids varied depending on the type of phosphates [93].

Rokhbakhsh-Zamin et al. [85] showed that of the 31 representatives of the genus Acinetobacter isolated from the rhizosphere of African millet, 26 strains showed the ability to solubilize phosphates. The most active phosphates mobilizing agent were strains $A$. calcoaceticus PUCM1006 and A. calcoaceticus PUCM1005, which under cultivation in medium with glucose $(10 \mathrm{~g} / \mathrm{L})$ and calcium triphosphate $(5 \mathrm{~g} / \mathrm{L})$ for 7 days formed 84 and $70 \mathrm{mg} / \mathrm{L}$ of soluble phosphates, respectively.

Ability to solubilize calcium triphosphate $(0.5 \%)$ by strain $A$. calcoaceticus D10 is established in the paper [86]. During the cultivation of this strain on a tryptic soy broth medium, the degree of phosphate solubilization after 6 days was $10 \mathrm{mg} / \mathrm{L}$.

Syed-Ab-Rahman et al. [87] investigated the phosphate-mobilizing properties of Acinetobacter sp. UQ154, UQ156 and UQ202 strains when grown on agar medium with dextrose $(10 \mathrm{~g} / \mathrm{L})$ and calcium triphosphate $(5 \mathrm{~g} / \mathrm{L})$. The phosphate solubilization index for all strains was almost the same and amounted to $2.2-2.36$ (this indicator was calculated as the ratio of the sum of the diameter of the clarification zone and the colony diameter to the colony diameter).

In the paper [94] was found that Acinetobacter sp. CGMCC 13078 is capable of solubilizing both inorganic and organic phosphates. Strain CGMCC 13078, when grown in a liquid medium with glucose $(10 \mathrm{~g} / \mathrm{L})$ and calcium triphosphate $(10 \mathrm{~g} / \mathrm{L})$, synthesized formic acid in an amount of 170.4, which was accompanied by the formation of $402 \mathrm{mg} / \mathrm{L}$ of soluble phosphate after 5 days [94].

In 2020, a paper was published [95], which reports the isolation of the Acinetobacter sp. SK2 strain which, as a result of the formation of gluconic acid during growth on a glucose medium, solubilized $682 \mu \mathrm{g} / \mathrm{mL}$ of calcium triphosphate and $86 \mu \mathrm{g} / \mathrm{mL}$ of rock phosphate.

It should be noted that Acinetobacter sp. SK2 is a more effective phosphate mobilizing agent not only in comparison with representatives of the Acinetobacter genus [85, 86, 94], but also with other bacteria: Burkholderia cepacia $(51 \mu \mathrm{g} / \mathrm{mL})$, Klebsiella sp. $(110-130 \mu \mathrm{g} / \mathrm{mL})$ [96], Rhizobium sp. Td3 (423 $\mu \mathrm{g} / \mathrm{mL}), \mathrm{SN} 1$ (428 $\mu \mathrm{g} / \mathrm{mL})$ [97], Rhizobium sp. RM $(653 \mu \mathrm{g} / \mathrm{mL})$ and RS $(602 \mu \mathrm{g} / \mathrm{mL})$ [98].

Degradation of xenobiotics. Bacteria of the Acinetobacter genus are known for their ability 


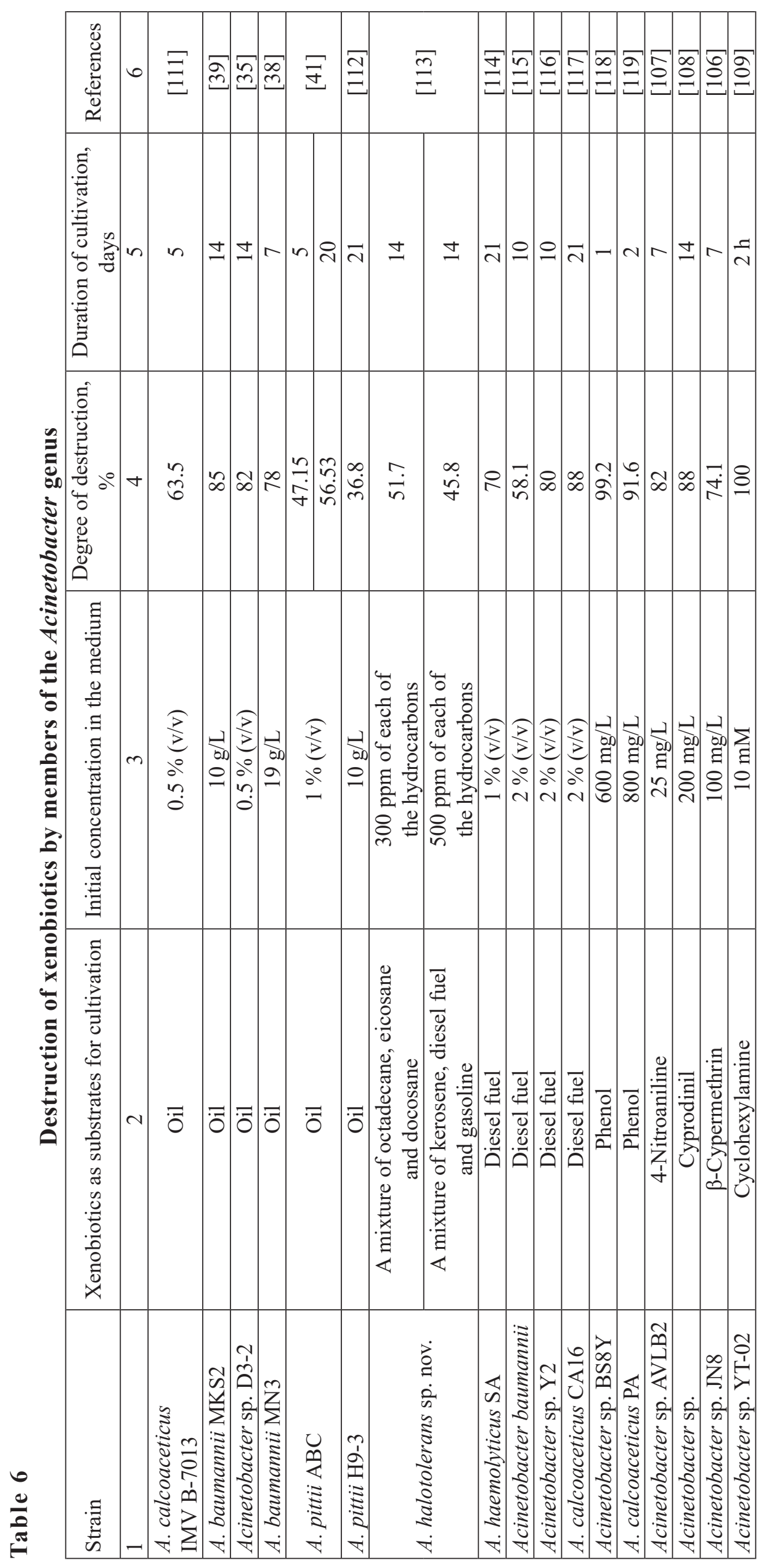


to degrade hydrocarbons, including n-alkanes [99-101], aromatic compounds [25, 102-104], and diesel fuel $[23,105]$. The latest information appeared on the participation of representatives of this genus in the decomposition of pesticides [106-108] and insecticides [109, 110]. It should be noted that the ability to decompose xenobiotics was established by researchers during the cultivation of Acinetobacter genus bacteria on media containing toxic compounds as growing media (Table 6). In addition, in the papers [35, 38, 39, 41, 111] the authors focused on the role of synthesized biosurfactants as one of the factors that ensure a sufficiently high degree of decomposition of toxic substances.

In our studies [120], the ability of A. calcoaceticus IMV B-7241 to decompose aromatic compounds with simultaneous synthesis of extracellular metabolites with surface-active and emulsifying properties was determined. In the presence of biosurfactants A. calcoaceticus IMV B-7241 in the form of postfermentation culture liquid $(5-10 \%)$ the degree of degradation of complex oil pollutants with heavy metals $\left(\mathrm{Ci}^{2+}\right.$, $\left.\mathrm{Cd}^{2+}, \mathrm{Pb}^{2+}, 0.01-0.5 \mathrm{mM}\right)$ in water $(3-6 \mathrm{~g} / \mathrm{L})$ and soil $(20 \mathrm{~g} / \mathrm{kg})$ after 20 days was $82-92 \%$.

The data given in Table 6 indicate that the level of decomposition of oil, diesel fuel and aromatic compounds by representatives of the Acinetobacter genus is comparable to the potential of actinobacteria of the Rhodococcus genus, which are among the most active xenobiotic decomposer among microorganisms $[9,121]$.

$$
* * *
$$

Analysis of literature data has shown that since the end of the 70 s of the twentieth century and over the next 20-25 years, the main interest in Acinetobacter genus bacteria was due to producers of high-molecular emulsifiers. However, the situation has changed dramatically in the last decade. Currently, it is established that Acinetobacter genus representatives are capable not only of the synthesis of high-molecular emulsifiers, but also of low-molecular biosurfactants, promising for use in environmental technologies, practically valuable enzymes in particular, agarase and chondroitinase, and the ability to form phytohormones and solubilize phosphates determines the possibility of their practical use in crop production to increase crop yields. In addition, Acinetobacter bacteria are effective decomposers of aliphatic and aromatic hydrocarbons, as well as pesticides and insecticides. Every year the number of publications on the practically valuable properties of non- pathogenic bacteria of the Acinetobacter genus and the metabolites synthesized by them increases, which indicates their potential as promising an objects of biotechnology.

\section{БІОТЕХНОЛОГІЧНИЙ ПОТЕНЦАЛ БАКТЕРІЙ РОДУ ACINETOBACTER}

\section{Т.П. Пирог ${ }^{1,2}$, Д.А. Луцай ${ }^{1}$ Ф.В. Мучник ${ }^{2}$}

${ }^{1}$ Національний університет харчових технологій, вул. Володимирська, 68, Київ, 01601, Україна

${ }^{2}$ Інститут мікробіології і вірусології ім. Д.К. Заболотного НАН Украӥни, вул. Академіка Заболотного, 154, Київ, 03143, Україна

\section{Резюме}

Донедавна літературні відомості про біотехнологічний потенціал непатогенних бактерій роду Acinetobacter були небагаточисельними, хоча перші повідомлення про практично цінні властивості цих бактерій датувалися 70-80-ми роками XX ст. і стосувалися синтезу біоемульгатора емульсану. В останнє десятиліття інтерес до представників роду Acinetobacter як об'єктів біотехнології суттєво підвищився. В огляді наведено сучасні дані літератури про синтез бактеріями цього роду високомолекулярних емульгаторів, низькомолекулярних поверхнево-активних речовин гліко- і аміноліпідної природи, ферментів (ліпази, агарази, хондроїтінази), фітогормонів, а також їх здатність до солюбілізації фосфатів і деструкції різних ксенобіотиків (аліфатичних та ароматичних вуглеводнів, пестицидів, інсектицидів). Біоемульгатори бактерій роду Acinetobacter залишаються об'єктом наукових досліджень і до теперішнього часу. Це, насамперед, зумовлене тим, що на відміну від інших продуктів мікробного синтезу, синтезованих широким колом мікроорганізмів, ці емульгатори $\epsilon$ «своєрідною візитівкою» представників роду Acinetobacter. Так, крім добре відомих і достатньо повно досліджених емульсанів, дисперсану, алазану, упродовж останніх десяти років описано нові перспективні для біоремедіації довкілля емульгатори, які за хімічною природою є глікопротеїнами, ліпополісахаридами і полісахаридами. Низькомолекулярні поверхнево-активні гліко- та ліпопептиди бактерій роду Acinetobacter досліджуються упродовж всього десяти років, тому вони не $\epsilon$ конкурентно спроможними на ринку цих продуктів мікробного синтезу. Основною причиною цього $\epsilon$ той факт, що утворення поверхнево-активних 
речовин розглядається як додаткова властивість мікроорганізмів-деструкторів гідрофобних токсичних сполук. Крім того, тільки останніми роками стали з'являтися повідомлення про біологічні (антимікробні, антиадгезивні та протипухлинні) властивості поверхнево-активних речовин представників роду Acinetobacter. Серед ферментів бактерій роду Acinetobacter найбільша увага приділена одержанню ліпаз, хоча за синтезувальною здатністю вони поступаються відомим у світі продуцентам. У той же час штам Acinetobacter sp. AG LSL-1 як продуцент агарази (активність 3 Од/мл) є перспективнішим за Alteromonas sp. C-1 (2,3 Од/мл), який був відкритий понад 15 років тому і вважався одним з найактивніших продуцентів цього ферменту. Штам Acinetobacter sp. C26 є перспективнішим продуцентом унікального ферменту хондроїтинази ( 8,5 Од/мл) порівняно 3 рекомбінантним штамом Pichia pastoris X33 (2,72 Од/мл). Дослідження бактерій роду Acinetobacter як фосфатмобілізувальних агентів розпочалося одночасно з вивченням їх здатності до синтезу ріст-стимулювальних метаболітів (фітогормонів, сідерофорів та ін.). Acinetobacter sp. SK2 є ефек-

1. Grady EN, MacDonald J, Liu L, Richman A, Yuan ZC. Current knowledge and perspectives of Paenibacillus: a review. Microb Cell Fact. 2016;15(1):203. doi: 10.1186/s12934-016-06037.

2. Contesini FJ, Melo RR, Sato HH. An overview of Bacillus proteases: from production to application. Crit Rev Biotechnol. 2018; 38(3):321-34. doi: 10.1080/07388551.2017.1354354.3.

3. Olishevska S, Nickzad A, Déziel E. Bacillus and Paenibacillus secreted polyketides and peptides involved in controlling human and plant pathogens. Appl Microbiol Biotechnol. 2019;103(3):1189-1215. doi: 10.1007/s00253018-9541-0.

4. Procópio RE, Silva IR, Martins MK, Azevedo JL, Araújo JM. Antibiotics produced by Streptomyces. Braz J Infect Dis. 2012;16(5):466-71. doi: 10.1016/j.bjid.2012.08.014.

5. Xiao L, Deng Z, Liu T. [Progress in developing and applying Streptomyces chassis: a review]. Wei Sheng Wu Xue Bao. 2016; 56(3):441-53. Chinese. тивнішим фосфатмобілізуючим агентом (утворення 682 мкг/мл розчинного фосфату) не тільки порівняно $з$ представниками роду Acinetobacter, а й симбіотичними азотфіксаторами роду Rhizobium, які солюбілізують 423-653 мкг/мл фосфатів. Наведено дані власних експериментальних досліджень про синтез та біологічну активність (антимікробну, антиадгезивну, здатність до руйнування біоплівок) поверхнево-активних речовин, синтезованих штамом $A$. calcoaceticus IMB B-7241, та їх роль у деструкції нафтових, у тому числі й комплексних з важкими металами, забруднень. Здатність A. calcoaceticus IMB B-7241 до одночасного синтезу фітогормонів (ауксини, цитокініни, гібереліни) та поверхнево-активних речовин з антимікробною щодо фітопатогенних бактерій активністю дає змогу розглядати цей штам як перспективний для практичного використання у рослинництві для підвищення врожайності сільськогосподарських культур.

Ключові слова: рід Acinetobacter, поверхневоактивні речовини, біоемульгатори, ферменти, фітогормони, деструкція ксенобіотиків.

6. Bilal M, Guo S, Iqbal HMN, $\mathrm{Hu} \mathrm{H}$, Wang W, Zhang X. Engineering Pseudomonas for phenazine biosynthesis, regulation, and biotechnological applications: a review. World J Microbiol Biotechnol. 2017; 33(10):191. doi: 10.1007/ s11274-017-2356-9.

7. Jiang J, Zu Y, Li X, Meng Q, Long X. Recent progress towards industrial rhamnolipids fermentation: process optimization and foam control. Bioresour Technol. 2020; 298:122394. doi: 10.1016/j.biortech.2019.122394.

8. Cappelletti M, Presentato A, Piacenza E, Firrincieli A, Turner RJ, Zannoni D. Biotechnology of Rhodococcus for the production of valuable compounds. Appl Microbiol Biotechnol. 2020;104(20):8567-94. doi: 10.1007/s00253020-10861-z.

9. Pirog TP, Petrenko NM, Skrotska OI, Paliichuk OI, Shevchuk TA, Iutynska GO. Practically valuable properties of the surfactant synthesized by Rhodococcus genus actinobacteria. Mikrobiol Z. 2020; 82(4):94-109. doi: https://doi. org/10.15407/microbiolj82.04.094 
10. Jung J, Park W. Acinetobacter species as model microorganisms in environmental microbiology: current state and perspectives. Appl Microbiol Biotechnol. 2015; 99(6):2533-48. doi: 10.1007/ s00253-015-6439-y.

11. Al Atrouni A, Joly-Guillou ML, Hamze M, Kempf M. Reservoirs of non-baumannii Acinetobacter species. Front Microbiol. 2016; 7:49. doi: 10.3389/fmicb.2016.00049.

12. Askari N, Momtaz H, Tajbakhsh E. Acinetobacter baumannii in sheep, goat, and camel raw meat: virulence and antibiotic resistance pattern. AIMS Microbiol. 2019; 5(3):272-84. doi: 10.3934/microbiol.2019.3.272.

13. Malta RCR, Ramos GLPA, Nascimento JDS. From food to hospital: we need to talk about Acinetobacter spp. Germs. 2020; 10(4):210-7. doi: 10.18683/germs.2020.1207.

14. Zhao YH, Chen LY, Tian ZJ, Sun Y, Liu JB, Huang L. Characterization and application of a novel bioemulsifier in crude oil degradation by Acinetobacter beijerinckii ZRS. J Basic Microbiol. 2016; 56(2):184-95. doi: 10.1002/ jobm.201500487.

15. Vázquez-Vázquez JL, Ortega-de ND, Huerta-Ochoa S, Gimeno M. Novel exopolysaccharide produced by Acinetobacter bouvetii UAM25: production, characterization and PAHs bioemulsifying capability. Revista Mexicana de Ingenier1a Quımica. 2017, 16(3):721-33.

16. Adetunji AI, Olaniran AO. Production and characterization of bioemulsifiers from Acinetobacter strains isolated from lipid-rich wastewater. Biotech. 2019; 9(4):151. doi: 10.1007/s13205-0191683-y.

17. Chen J, Huang PT, Zhang KY, Ding FR. Isolation of biosurfactant producers, optimization and properties of biosurfactant produced by Acinetobacter sp. from petroleum-contaminated soil. J Appl Microbiol. 2012;112(4):660-71. doi: 10.1111/j.1365-2672.2012.05242.x.

18. Dong H, Xia W, Dong H, She Y, Zhu P, Liang $\mathrm{K}$, et al. Rhamnolipids produced by indigenous Acinetobacter junii from petroleum reservoir and its potential in enhanced oil recovery. Front Microbiol. 2016;7:1710. doi: 10.3389/ fmicb.2016.01710.
19. Zhu C, Zhang J, Zhang J, Jiang Y, Shen Z, Guan H, et al. Purification and characterization of chondroitinase ABC from Acinetobacter sp. C26. Int J Biol Macromol. 2017; 95:80-6. doi: 10.1016/ j.ijbiomac.2016.10.044.

20. Ahmed EH, Raghavendra T, Madamwar D. An alkaline lipase from organic solvent tolerant Acinetobacter sp. EH28: application for ethyl caprylate synthesis. Bioresour Technol. 2010;101(10):3628-34. doi: 10.1016/j. biortech.2009.12.107.

21. Kang SM, Joo GJ, Hamayun M, Na CI, Shin DH, Kim HY, et al. Gibberellin production and phosphate solubilization by newly isolated strain of Acinetobacter calcoaceticus and its effect on plant growth. Biotechnol Lett. 2009; 31(2):277-81. doi: 10.1007/s10529-008-9867-2.

22. Gulati A, Vyas P, Rahi P, Kasana RC. Plant growth-promoting and rhizosphere-competent Acinetobacter rhizosphaerae strain BIHB 723 from the cold deserts of the Himalayas. Curr Microbiol. 2009; 58(4):371-7. doi: 10.1007/ s00284-008-9339-x.

23. Lee M, Woo SG, Ten LN. Characterization of novel diesel-degrading strains Acinetobacter haemolyticus MJ01 and Acinetobacter johnsonii MJ4 isolated from oil-contaminated soil. World J Microbiol Biotechnol. 2012; 28(5):2057-67. doi: 10.1007/s11274-012-1008-3.

24. Wang W, Chen X, Yan H, Hu J, Liu X. Complete genome sequence of the cyprodinil-degrading bacterium Acinetobacter johnsonii LXL_C1. Microb Pathog. 2019;127:246-9. doi: 10.1016/j. micpath.2018.11.016.

25. Sharma V, Lin J. Draft genome sequence of phenol degrading Acinetobacter sp. strain V2, isolated from oil contaminated soil. Braz J Microbiol. 2017; 48(2):189-90. doi: 10.1016/j. bjm.2016.06.015.

26. Rosenberg E, Zuckerberg A, Rubinovitz C, Gutnick DL. Emulsifier of Arthrobacter RAG-1: isolation and emulsifying properties. Appl Environ Microbiol. 1979; 37(3):402-8. doi: 10.1128/ AEM.37.3.402-408.1979.

27. Rosenberg E, Perry A, Gibson DT, Gutnick DL. Emulsifier of Arthrobacter RAG-1: specificity of hydrocarbon substrate. Appl Environ Microbiol. 
1979; 37(3):409-13. doi: 10.1128/AEM.37.3. 409-413.1979.

28. Zuckerberg A, Diver A, Peeri Z, Gutnick DL, Rosenberg E. Emulsifier of Arthrobacter RAG-1: chemical and physical properties. Appl Environ Microbiol. 1979; 37(3):414-20. doi: 10.1128/ AEM.37.3.414-420.1979

29. Zhao Z, Wong JW. Biosurfactants from Acinetobacter calcoaceticus BU03 enhance the solubility and biodegradation of phenanthrene. Environ Technol. 2009; 30(3):291-9. doi: 10.1080/09593330802630801.

30. Pirog TP, Antonyuk SI, Karpenko YV, Shevchuk TA. The influence of conditions of Acinetobacter calcoaceticus $\mathrm{K}-4$ strain cultivation on surface-active substances synthesis. Appl Biochem Microbiol 2009; 45: 272-8. https://doi. org/10.1134/S0003683809030065

31. Rooney AP, Price NP, Ray KJ, Kuo TM. Isolation and characterization of rhamnolipid-producing bacterial strains from a biodiesel facility. FEMS Microbiol Lett. 2009; 295(1):82-7. doi: 10.1111/j.1574-6968.2009.01581.x.

32. Hošková $M$, Schreiberová $\mathrm{O}$, Ježdík R, Chudoba J, Masák J, Sigler K, et al. Characterization of rhamnolipids produced by non-pathogenic Acinetobacter and Enterobacter bacteria. Bioresour Technol. 2013;130:510-6. doi: 10.1016/j. biortech.2012.12.085.

33. Prakasam G, Anusha R, Ramesh SS. Rhamnolipid production among clinical and skin isolates of healthy individuals of Acinetobacter species: The first report. Int J Appl Basic Med Res. 2013; 3(2):133. doi: 10.4103/2229-516X.11710

34. Hošková M, Ježdík R, Schreiberová O, Chudoba J, Šír M, Čejková A, et al. Structural and physiochemical characterization of rhamnolipids produced by Acinetobacter calcoaceticus, Enterobacter asburiae and Pseudomonas aeruginosa in single strain and mixed cultures. J Biotechnol. 2015;193:45-51. doi: 10.1016/j. jbiotec.2014.11.014.

35. Bao M, Pi Y, Wang L, Sun P, Li Y, Cao L. Lipopeptide biosurfactant production bacteria Acinetobacter sp. D3-2 and its biodegradation of crude oil. Environ Sci Process Impacts. 2014;16(4):897-903. doi: 10.1039/c3em00600j.
36. Zou C, Wang M, Xing Y, Lan G, Ge T, Yan X, et al. Characterization and optimization of biosurfactants produced by Acinetobacter baylyi $\mathrm{ZJ} 2$ isolated from crude oil-contaminated soil sample toward microbial enhanced oil recovery applications. Biochem Eng J. 2014; 90:49-58. https://doi.org/10.1016/j.bej.2014.05.007

37. Khan A, Tanveer S, Alia S, Anees M, Sultan A, Iqbal $\mathrm{M}$, et al. Role of nutrients in bacterial biosurfactant production and effect of biosurfactant production on petroleum hydrocarbon biodegradation. Ecol Eng. 2017; 104:158-64. https://doi. org/10.1016/j.ecoleng.2017.04.023

38. Parthipan P, Elumalai P, Sathishkumar K, Sabarinathan D, Murugan K, Benelli G, et al. Biosurfactant and enzyme mediated crude oil degradation by Pseudomonas stutzeri NA3 and Acinetobacter baumannii MN3. Biotech. 2017; 7(5):278. doi: 10.1007/s13205-017-0902-7.

39. Muthukamalam S, Sivagangavathi S, Dhrishya D, Sudha Rani S. Characterization of dioxygenases and biosurfactants produced by crude oil degrading soil bacteria. Braz J Microbiol. 2017; 48(4):637-47. doi: 10.1016/j.bjm.2017.02.007.

40. Ohadi M, Dehghannoudeh G, Forootanfar H, Shakibaie M, Rajaee M. Investigation of the structural, physicochemical properties, and aggregation behavior of lipopeptide biosurfactant produced by Acinetobacter junii B6. Int J Biol Macromol. 2018;112:712-9. doi: 10.1016/j.ijbiomac.2018.01.209.

41. Chettri B, Singha NA, Mukherjee A, Rai AN, Chattopadhyay D, Singh AK. Hydrocarbon degradation potential and competitive persistence of hydrocarbonoclastic bacterium Acinetobacter pittii strain ABC. Arch Microbiol. 2019; 201(8):1129-40. doi: 10.1007/s00203-01901687-z.

42. Ohadi M, Forootanfar H, Dehghannoudeh G, Eslaminejad T, Ameri A, Shakibaie M, et al. Antimicrobial, anti-biofilm, and anti-proliferative activities of lipopeptide biosurfactant produced by Acinetobacter junii B6. Microb Pathog. 2020; 138:103806. doi:10.1016/j.micpath.2019.103806.

43. Yuan H, Yao J, Masakorala K, Wang F, Cai M, $\mathrm{Yu}$ C. Isolation and characterization of a newly 
isolated pyrene-degrading Acinetobacter strain USTB-X. Environ Sci Pollut Res Int. 2014; 21(4):2724-32. doi: 10.1007/s11356-013-22219.

44. Shalini D, Benson A, Gomathi R, Henry AJ, Jerritta $\mathrm{S}$, Melvin Joe $\mathrm{M}$. Isolation, characterization of glycolipid type biosurfactant from endophytic Acinetobacter sp. ACMS25 and evaluation of its biocontrol efficiency against Xanthomonas oryzae. Biocatal Agric Biotechnol. 2017; 11:252-8. doi:10.1016/j.bcab.2017.07.013

45. Karlapudi AP, Venkateswarulu TC, Srirama K, Kota RK, Mikkili I, Kodali VP. Evaluation of anti-cancer, anti-microbial and anti-biofilm potential of biosurfactant extracted from an Acinetobacter M6 strain. J King Saud Univer. 2020; 32(1):223-7. https://doi.org/10.1016/j.jksus. 2018.04.007

46. Mujumdar S, Joshi P, Karve N. Production, characterization, and applications of bioemulsifiers (BE) and biosurfactants (BS) produced by Acinetobacter spp.: a review. J Basic Microbiol. 2019; 59(3):277-87. doi: 10.1002/jobm.201800364.

47. Pirog TP, Nikituk LV, Antonuk SI, Shevchuk TA, Iutynskaya GA. [Intensification of Acinetobacter calcoaceticus IMV B-7241 surfactants synthesis on waste sunflower oil]. Mikrobiol Z. 2018; 80(1):15-26. Russian. doi: https://doi. org/10.15407/microbiolj80.01.015

48. Pirog T, Shulyakova M, Sofilkanych A, Shevchuk T, Mashchenko O. Biosurfactant synthesis by Rhodococcus erythropolis IMV Ac-5017, Acinetobacter calcoaceticus IMV B-7241 and Nocardia vaccinii IMV B-7405 on byproduct of biodiesel production. Food Bioprod Process. 2015; 93:11-8. https://doi.org/10.1016/j.fbp. 2013.09.003

49. Pirog TP, Konon AD, Beregovaya KA, Shulyakova MA. Antiadhesive properties of the surfactants of Acinetobacter calcoaceticus IMB B-7241, Rhodococcus erythropolis IMB Ac-5017, and Nocardia vaccinii IMB B-7405. Microbiology. 2014; 83(6):732-9. https://doi.org/10.1134/ S0026261714060150

50. Pirog TP, Savenko IV, Shevchuk TA. [Effect of cultivation condition of Acinetobacter calcoaceticus IMV B-7241 on antiadhesive properties of surfactants]. Mikrobiol Z. 2016; 78(1):2-12. Russian. https://doi.org/10.15407/microbiolj78.01.002

51. Pirog TP, Savenko IV, Shevchuk TA, Krutous NV, Iutynska GO. [Antimicrobial poperties surfactants synthesized under different cultivation conditions of Acinetobacter calcoaceticus EMV B-7241]. Mikrobiol Z. 2016; 78(3):2-12. Ukrainian. https://doi.org/10.15407/microbiolj78.03.002

52. Pirog TP, Savenko IV, Lutsai DA, Shevchuk TA, Iutynska GO. [The role of Acinetobacter calcoaceticus IMV B-7241 surfactants in biofilms destruction]. Mikrobiol Z. 2017; 79(4):21-9. Russian. https://doi.org/10.15407/microbiolj79.04.021

53. Pirog TP, Lutsai DA, Shevchuk TA, Iutynska GO, Elperin IV. [Antimicrobial and anti-adhesive activity of surfactants synthesized by Acinetobacter calcoaceticus IMV B-7241 on technical glycerol]. Mikrobiol Z. 2018; 80(2):14-27. Ukrainian. https://doi.org/10.15407/microbiolj80.02.014

54. Pirog TP, Lutsai DA, Antonuk SI, Elperin IV. The properties of surfactants synthesized by Acinetobacter calcoaceticus IMV B-7241 on refined and waste sunflower oil. Biotechnologia Acta. 2018; 11 (6):82-91. https://doi.org/10.15407/ biotech11.06.082

55. Bayer EA, Rosenberg E, Gutnick D. The isolation of cell surface mutants of Acinetobacter calcoaceticus RAG-1. J Gen Microbiol. 1981; 127(2):295-300. doi: 10.1099/00221287-127-2295.

56. Vaneechoutte M, Tjernberg I, Baldi F, Pepi M, Fani R, Sullivan ER, et al. Oil-degrading Acinetobacter strain RAG-1 and strains described as 'Acinetobacter venetianus sp. nov.' belong to the same genomic species. Res Microbiol. 1999; 150(1):69-73. doi: 10.1016/s09232508(99)80047-3.

57. Kaplan N, Zosim Z, Rosenberg E. Reconstitution of emulsifying activity of Acinetobacter calcoaceticus BD4 emulsan by using pure polysaccharide and protein. Appl Environ Microbiol. 1987; 53(2):440-6. doi: 10.1128/AEM.53.2.440446.1987. 
58. Rosenberg E, Rubinovitz C, Gottlieb A, Rosenhak S, Ron EZ. Production of biodispersan by Acinetobacter calcoaceticus A2. Appl Environ Microbiol. 1988; 54(2):317-22. doi: 10.1128/ AEM.54.2.317-322.

59. Rosenberg E, Schwartz Z, Tenenbaum A, Rubinovitz C, Legmann R, Ron EZ. A microbial polymer that changes the surface properties of limestone: effect of biodispersan in grinding limestone and making paper. J Dispersion Sci Technol. 1989; 10(3):241-50.

60. Navon-Venezia S, Zosim Z, Gottlieb A, Legmann R, Carmeli S, Ron EZ, et al. Alasan, a new bioemulsifier from Acinetobacter radioresistens. Appl Environ Microbiol. 1995; 61(9):3240-4. doi: 10.1128/AEM.61.9.3240-3244.1995.

61. Rosenberg E, Ron EZ. High- and low-molecular-mass microbial surfactants. Appl Microbiol Biotechnol. 1999; 52(2):154-62. doi: 10.1007/ s002530051502.

62. Mercaldi MP, Dams-Kozlowska H, Panilaitis B, Joyce AP, Kaplan DL. Discovery of the dual polysaccharide composition of emulsan and the isolation of the emulsion stabilizing component. Biomacromolecules. 2008; 9(7):1988-96. doi: 10.1021/bm800239p.

63. Mnif I, Ghribi D. High molecular weight bioemulsifiers, main properties and potential environmental and biomedical applications. World J Microbiol Biotechnol. 2015; 31(5):691-706. doi: 10.1007/s11274-015-1830-5.

64. Alizadeh-Sani M, Hamishehkar H, Khezerlou A, Azizi-Lalabadi M, Azadi Y, Nattagh-Eshtivani E, et al. Bioemulsifiers derived from microorganisms: applications in the drug and food industry. Adv Pharm Bull. 2018; 8(2):191-9. doi: 10.15171/apb.2018.023.

65. Jagtap S, Yavankar S, Pardesi K, Chopade B. Production of bioemulsifier by Acinetobacter species isolated from healthy human skin. Indian J Exp Biol. 2010; 48(1):70-6.

66. Ortega-de la Rosa ND, Vázquez-Vázquez JL, Huerta-Ochoa S, Gimeno M, Gutiérrez-Rojas M. Stable bioemulsifiers are produced by Acinetobacter bouvetii UAM25 growing in different carbon sources. Bioprocess Biosyst Eng. 2018; 41(6):859-69. doi: 10.1007/s00449-018-1920-5.
67. Wang HK, Shao J, Wei YJ, Zhang J, Qi W. A novel low-temperature alkaline lipase from Acinetobacter johnsonii LP28 suitable for detergent formulation. Food Technol Biotechnol. 2011; 49 (1): 96-102.

68. Zheng X, Chu X, Zhang W, Wu N, Fan Y. A novel cold-adapted lipase from Acinetobacter sp. XMZ-26: gene cloning and characterisation. Appl Microbiol Biotechnol. 2011; 90(3):971-80. doi: 10.1007/s00253-011-3154-1.

69. Gururaj P, Ramalingam S, Nandhini Devi G, Gautam P. Process optimization for production and purification of a thermostable, organic solvent tolerant lipase from Acinetobacter sp. AU07. Braz J Microbiol. 2016; 47(3):647-57. doi: 10.1016/j.bjm.2015.04.002

70. De Santi C, Altermark B, de Pascale D, Willassen NP. Bioprospecting around arctic islands: marine bacteria as rich source of biocatalysts. J Basic Microbiol. 2016; 56(3):238-53. doi: 10.1002/jobm.201500505.

71. Bharathi D., Rajalakshmi G. Microbial lipases: an overview of screening, production and purification. Biocatal Agricultur Biotechnol. 2019. doi:10.1016/j.bcab.2019.101368.

72. Filho DG, Silva AG, Guidini CZ. Lipases: sources, immobilization methods, and industrial applications. Appl Microbiol Biotechnol. 2019; 103(18):7399-423. doi: 10.1007/s00253-01910027-6.

73. Chandra P, Enespa, Singh R, Arora PK. Microbial lipases and their industrial applications: a comprehensive review. Microb Cell Fact. 2020; 19(1):169. doi: 10.1186/s12934-020-01428-8.

74. Patel R, Prajapati V, Trivedi U, Patel K. Optimization of organic solvent-tolerant lipase production by Acinetobacter sp. UBT1 using deoiled castor seed cake. Biotech. 2020; 10(12):508. doi: 10.1007/s13205-020-02501-0.

75. Lakshmikanth M, Manohar S, Lalitha J. Purification and characterization of $\beta$-agarase from agar-liquefying soil bacterium, Acinetobacter sp., AG LSL-1. Process Biochem. 2009; 44 (9): 999-1003.

76. Leema Roseline T, Sachindra N. Characterization of extracellular agarase production by Acinetobacter junii PS12B, isolated from marine sed- 
iments. Biocatal Agricultur Biotechnol. 2016; 6:219-26.

77. Snellman EA, Colwell RR. Acinetobacter lipases: molecular biology, biochemical properties and biotechnological potential. J Ind Microbiol Biotechnol. 2004; 31(9):391-400. doi: 10.1007/ s10295-004-0167-0.

78. Bradbury EJ, Carter LM. Manipulating the glial scar: chondroitinase $\mathrm{ABC}$ as a therapy for spinal cord injury. Brain Res Bull. 2011; 84(4-5):30616. doi: 10.1016/j.brainresbull.2010.06.015.

79. DePaul MA, Lin CY, Silver J, Lee YS. Combinatory repair strategy to promote axon regeneration and functional recovery after chronic spinal cord injury. Sci Rep. 2017; 7(1):9018. doi: 10.1038/ s41598-017-09432-6.

80. Tran AP, Warren PM, Silver J. The biology of regeneration failure and success after spinal cord injury. Physiol Rev. 2018; 98(2):881-917. doi: 10.1152/physrev.00017.2017.

81. Muir E, De Winter F, Verhaagen J, Fawcett J. Recent advances in the therapeutic uses of chondroitinase ABC. Exp Neurol. 2019; 321:113032. doi: 10.1016/j.expneurol.2019.113032.

82. Hong SW, Kim BT, Shin HY, Kim WS, Lee KS, Kim YS, et al. Purification and characterization of novel chondroitin ABC and AC lyases from Bacteroides stercoris HJ-15, a human intestinal anaerobic bacterium. Eur J Biochem. 2002; 269(12):2934-40. doi: 10.1046/j.14321033.2002.02967.x.

83. Fu J, Jiang Z, Chang J, Han B, Liu W, Peng Y. Purification, characterization of chondroitinase ABC from Sphingomonas paucimobilis and in vitro cardiocytoprotection of the enzymatically degraded CS-A. Int J Biol Macromol. 2018; 115:737-45. doi: 10.1016/j.ijbiomac. 2018.04.117.

84. Fang Y, Yang S, Fu X, Xie W, Li L, Liu Z, et al. Expression, purification and characterization of chondroitinase AC II from marine bacterium Arthrobacter sp. CS01. Mar Drugs. 2019; 17(3):185. doi: 10.3390/md17030185.

85. Rokhbakhsh-Zamin F, Sachdev D, Kazemi-Pour N, Engineer A, Pardesi KR, Zinjarde S, et al. Characterization of plant-growth-promoting traits of Acinetobacter species isolated from rhi- zosphere of Pennisetum glaucum. J Microbiol Biotechnol. 2011; 21(6):556-66.

86. Zhao L, Wang F, Zhao J. Identification and functional characteristics of chlorpyrifos-degrading and plant growth promoting bacterium Acinetobacter calcoaceticus. J Basic Microbiol. 2014; 54(5):457-63. doi: 10.1002/jobm.201200639.

87. Syed-Ab-Rahman SF, Carvalhais LC, Chua E, Xiao Y, Wass TJ, Schenk PM. Identification of soil bacterial isolates suppressing different $P h y$ tophthora spp. and promoting plant growth. Front Plant Sci. 2018; 9:1502. doi: 10.3389/ fpls.2018.01502.

88. Lutz S, Thuerig B, Oberhaensli T, Mayerhofer J, Fuchs JG, Widmer F, et al. Harnessing the microbiomes of suppressive composts for plant protection: from metagenomes to beneficial microorganisms and reliable diagnostics. Front Microbiol. 2020;11:1810. doi: 10.3389/ fmicb.2020.01810.

89. Pirog T, Leonova N, Shevchuk T, Savenko I, Iutinska H. [Synthesis of phytohormones bacteria of Acinetobacter calcoaceticus IMV B-7241, Rhodococcus erythropolis IMV Ac-5017 and Nocardia vaccinii IMV B-7405 - producers of surface-active substances]. Proceedings of the National Academy of Sciences of Belarus. Biological series. 2017; (1):90-5. Russian.

90. Pirog TP, Havrylkina DV, Leonova NO, Shevchuk TA, Iutynska GO. [Synthesis of biologically active gibberellins $\mathrm{GA}_{4}$ and $\mathrm{GA}_{7}$ by microorganisms]. Mikrobiol Z. 2019; 81(2):90-109. https://doi.org/10.15407/microbiolj81.02.090 Ukrainian.

91. Pirog T, Leonova N, Piatetska D, Klymenko N, Shevchuk T. Influence of tryptophan on auxin-synthesizing ability of surfactant producer Acinetobacter calcoaceticus IMV B-7241. Ukrainian Food J. 2020; 9(1):175-84. http:// ufj.ho.ua/Archiv/UKRAINIAN\%20FOOD\%20 JOURNAL\%202020\%20V.9\%20Is.1.pdf

92. Pirog TP, Konon AD, Sofilkanich AP, Iutinskaia GA. Effect of surface-active substances of Acinetobacter calcoaceticus IMV B-7241, Rhodococcus erythropolis IMV Ac-5017, and Nocardia vaccinii K-8 on phytopathogenic bacteria. Appl Biochem Microbiol. 2013; 49(4):360-7. https:// 
doi:10.1134/S000368381304011X

93. Gulati A, Sharma N, Vyas P, Sood S, Rahi P, Pathania V, et al. Organic acid production and plant growth promotion as a function of phosphate solubilization by Acinetobacter rhizosphaerae strain BIHB 723 isolated from the cold deserts of the trans-Himalayas. Arch Microbiol. 2010; 192(11):975-83. doi: 10.1007/s00203010-0615-3.

94. Li C, Li Q, Wang Z, Ji G, Zhao H, Gao F, et al. Environmental fungi and bacteria facilitate lecithin decomposition and the transformation of phosphorus to apatite. Sci Rep. 2019; 9(1):15291. doi: 10.1038/s41598-019-51804-7.

95. Bharwad K, Rajkumar S. Modulation of PQQdependent glucose dehydrogenase (mGDH and sGDH) activity by succinate in phosphate solubilizing plant growth promoting Acinetobacter sp. SK2. Biotech. 2020; 10(1):5. doi: 10.1007/ s13205-019-1991-2.

96. Rajput MS, Naresh Kumar G, Rajkumar S. Repression of oxalic acid-mediated mineral phosphate solubilization in rhizospheric isolates of Klebsiella pneumoniae by succinate. Arch Microbiol. 2013; 195(2):81-8. doi: 10.1007/ s00203-012-0850-X.

97. Iyer B, Rajkumar S. Succinate irrepressible periplasmic glucose dehydrogenase of Rhizobium sp. Td3 and SN1 contributes to its phosphate solubilization ability. Arch Microbiol. 2019; 201(5):649-59. doi: 10.1007/s00203-019-016302.

98. Joshi E, Iyer B, Rajkumar S. Glucose and arabinose dependent mineral phosphate solubilization and its succinate-mediated catabolite repression in Rhizobium sp. RM and RS. J Biosci Bioeng. 2019; 128(5):551-7. doi: 10.1016/j. jbiosc.2019.04.020.

99. Espeche ME, MacCormack WP, Fraile ER. Factors affecting growth of an n-hexadecane degrader Acinetobacter species isolated from a highly polluted urban river. Int Biodeterior Biodegrad. 1994; 33:187-96.

100. Di Cello F, Pepi M, Baldi F, Fani R. Molecular characterization of an n-alkane-degrading bacterial community and identification of a new species, Acinetobacter venetianus. Res Microbi- ol. 1997; 148(3):237-49. doi: 10.1016/S09232508(97)85244-8

101. Throne-Holst M, Markussen S, Winnberg A, Ellingsen TE, Kotlar HK, Zotchev SB. Utilization of n-alkanes by a newly isolated strain of Acinetobacter venetianus: the role of two AlkB-type alkane hydroxylases. Appl Microbiol Biotechnol. 2006; 72(2):353-60. doi: 10.1007/s00253-0050262-9.

102. Adebusoye SA, Ilori MO, Amund OO, Teniola OD, Olatope SO. Microbial degradation of petroleum hydrocarbons in a polluted tropical stream. World J Microbiol Biotechnol. 2007; 23:1149-59. https://doi.org/10.1007/s11274-0079345-3

103. Fischer R, Bleichrodt FS, Gerischer UC. Aromatic degradative pathways in Acinetobacter baylyi underlie carbon catabolite repression. Microbiology (Reading). 2008;154(Pt 10):3095-103. doi: 10.1099/mic.0.2008/016907-0.

104. Sharma V, Lin J. Draft genome sequence of phenol degrading Acinetobacter sp. strain V2, isolated from oil contaminated soil. Braz J Microbiol. 2017; 48(2):189-90. doi: 10.1016/j. bjm.2016.06.015.

105. Kang YS, Jung J, Jeon CO, Park W. Acinetobacter oleivorans sp. nov. is capable of adhering to and growing on diesel-oil. J Microbiol. 2011; 49(1):29-34. doi: 10.1007/s12275-011-0315-y.

106. Jin Z, Guo Q, Zhang Z, Yan T. Biodegradation of type II pyrethroids and major degraded products by a newly isolated Acinetobacter sp. strain JN8. Can J Microbiol. 2014; 60(8):541-5. doi: 10.1139/cjm-2014-0104.

107. Silambarasan S, Vangnai AS. Biodegradation of 4-nitroaniline by plant-growth promoting Acinetobacter sp. AVLB2 and toxicological analysis of its biodegradation metabolites. J Hazard Mater. 2016; 302:426-36. doi: 10.1016/j. jhazmat.2015.10.010.

108. Chen X, He S, Liu X, Hu J. Biobegradation and metabolic mechanism of cyprodinil by strain Acinetobacter sp. from a contaminated-agricultural soil in China. Ecotoxicol Environ Saf. 2018; 159:190-7. doi: 10.1016/j.ecoenv.2018.04.047.

109. Yan DZ, Gan YT, Zhou H, Liu J, Li X. Draft genome sequence of cyclohexylamine-degrad- 
ing strain Acinetobacter sp. YT-02 isolated. Curr Microbiol. 2018; 75(3):284-7. doi: 10.1007/ s00284-017-1377-9.

110. Zhou H, Han ZG, Fang T, Chen YY, Ning SB, Gan YT, et al. Characterization of a new cyclohexylamine oxidase from Acinetobacter sp. YT02. Front Microbiol. 2018; 9:2848. doi: 10.3389/ fmicb.2018.02848.

111. Pidgorskyi VS, Nogina TM. Biodegradation of petroleum hydrocarbons by Actinobacteria and Acinetobacteria strains producing biosurfactant. Mikrobiol Z. 2016; 78(6):92-103. doi: https:// doi.org/10.15407/microbiolj78.06.092.

112. Wang Y, Wang Q, Liu L. Crude oil degrading fingerprint and the overexpression of oxidase and invasive genes for n-hexadecane and crude oil degradation in the Acinetobacter pittii H9-3 strain. Int J Environ Res Public Health. 2019; 16(2):188. doi: 10.3390/ijerph16020188.

113. Dahal RH, Chaudhary DK, Kim J. Acinetobacter halotolerans sp. nov., a novel halotolerant, alkalitolerant, and hydrocarbon degrading bacterium, isolated from soil. Arch Microbiol. 2017; 199(5):701-10. doi: 10.1007/s00203-017-13492.

114. Diallo MM, Vural C, Şahar U, Ozdemir G. Kurstakin molecules facilitate diesel oil assimilation by Acinetobacter haemolyticus strain 2SA through overexpression of alkane hydroxylase genes. Environ Technol. 2019:1-15. doi: 10.1080/ 09593330.2019 .1689301$.

115. Nkem BM, Halimoon N, Yusoff FM, Johari WLW, Zakaria MP, Medipally SR, et al. Isolation, identification and diesel-oil biodegradation capacities of indigenous hydrocarbon-degrading strains of Cellulosimicrobium cellulans and
Acinetobacter baumannii from tarball at Terengganu beach, Malaysia. Mar Pollut Bull. 2016; 107:261-8.

116. Luo Q, Zhang JG, Shen XR, Fan ZQ, He Y, Hou DY. Isolation and characterization of marine diesel oil-degrading Acinetobacter sp. strain Y2. Ann Microbiol. 2013;63:633-40.

117. Ho MT, Li MSM, McDowell T, MacDonald J, Yuan ZC. Characterization and genomic analysis of a diesel-degrading bacterium, Acinetobacter calcoaceticus CA16, isolated from Canadian soil. BMC Biotechnol. 2020; 20(1):39. doi: 10.1186/ s12896-020-00632-z.

118. Jiang L, Ruan Q, Li R, Li T. Biodegradation of phenol by using free and immobilized cells of Acinetobacter sp. BS8Y. J Basic Microbiol. 2013; 53(3):224-30. doi: 10.1002/jobm.201100460.

119. Liu Z, Xie W, Li D, Peng Y, Li Z, Liu S. Biodegradation of phenol by bacteria strain Acinetobacter calcoaceticus PA isolated from phenolic wastewater. Int J Environ Res Public Health. 2016; 13(3):300. doi: 10.3390/ijerph13030300.

120. Pirog TP, Shulyakova MO, Nikituk LV, Antonuk SI, Elperin IV. Industrial waste bioconversion into surfactants by Rhodococcus erythropolis IMV Ac-5017, Acinetobacter calcoaceticus IMV B-7241 and Nocardia vaccinii IMV B-7405. Biotechnologia Acta. 2017; 10(2):22-33. https://doi. org/10.15407/biotech10.02.022

121. Zampolli J, Zeaiter Z, Di Canito A, Di Gennaro P. Genome analysis and -omics approaches provide new insights into the biodegradation potential of Rhodococcus. Appl Microbiol Biotechnol. 2019; 103(3):1069-80. doi:10.1007/s00253-0189539-7.

Received 13.01.2021 